Vol. 10 No. 1 Maret 2015

\title{
PENGARUH KOMPENSASI DAN PELATIHAN TERHADAP KINERJA KARYAWAN PT.PEGADAIAN ( PERSERO) KANWIL 1 MEDAN
}

\author{
Dina Sarah Syahreza \\ Dosen Jurusan Manajemen Fakultas Ekonomi Universitas Negeri Medan \\ Aulia Ridha Siregar \\ Alumni Jurusan Manajemen Fakultas Ekonomi Universitas Negeri Medan
}

\begin{abstract}
Abstrak
Tujuan penelitian ini adalah, untuk mengetahui pengaruh pemberian kompensasi dan pelatihan terhadap kinerja karyawan PT.Pegadaian(Persero) Kanwil 1 Medan. Dalam penelitian ini peneliti menggunakan sampel sebanyak 56 karyawan PT.Pegadaian (Persero) Kanwil 1 Medan. Sedangkan pengambilan sampel digunakan sampling jenuh atau sensus, artinya keseluruhan populasi digunakan sebagai sampel. Dan tehnik analisis data yang digunakan adalah Uji kualitas data, uji Asumsi Klasik, Uji Hipotesis, dan regresi linear berganda.Hasil penelitian Regresi Linear Berganda menunjukkan bahwa variabel kompensasi $\left(X_{1}\right)$ dan pelatihan $\left(X_{2}\right)$ memiliki pengaruh yang signifikan terhadap kinerja karyawan dengan signifikansi 0,001 dengan koefisien determinasi ( $\left.R^{2}\right)$ sebesar 2,09 (20,9\%). Secara simultan dan parsial, kedua variabel yaitu kompensasi $\left(X_{1}\right)$ dan Pelatihan $\left(X_{2}\right)$ juga menunjukkan adanya pengaruh yang signifikan terhadap kinerja karyawan dengan tingkat signifikansi masing- masing 0,43 dan 0,27. Berdasarkan hasil penelitian diatas dapat dikatakan bahwa variabel kompensasi dan pelatihan mempunyai pengaruh yang signifikan terhadap kinerja karyawan PT.Pegadaian (Persero) Kanwil 1 Medan. Dan variabel pelatihan memiliri pengaruh yang lebih besar terhadap kinerja karyawan PT. Pegadaian (Persero) Kanwil 1 Medan.
\end{abstract}

Kata kunci : Kompensasi, Pelatihan, Kinerja Karyawan

\section{PENDAHULUAN}

Dalam kondisi ekonomi global yang terus berkembang menuntut semua perusahaan untuk dapat terus bersaing. Dalam hal ini faktor- faktor produksi memegang peranan penting dalam pencapaian tujuan perusahaan. Salah satunya adalah sumberdaya manusia, keberadaan sumber daya manusia di dalam suatu perusahaan memegang peranan sangat penting. Tenaga kerja memiliki potensi yang besar untuk menjalankan aktivitas perusahaan. Potensi setiap sumber daya manusia yang ada dalam perusahaan harus dapat dimanfaatkan dengan sebaik-baiknya sehingga mampu memberikan output optimal. Tercapainya tujuan perusahaan tidak hanya tergantung pada peralatan modern, sarana dan prasarana yang lengkap, tetapi justru lebih tergantung pada manusia yang melaksanakan pekerjaan tersebut.

Menyadari betapa pentingnya sumber daya manusia bagi perusahaan, sudah selayaknya perusahaan memberikan perhatian 
Vol. 10 No. 1 Maret 2015

khusus pada sumber daya ini. Dengan mengeluarkan peraturan atau kebijakan yang dapat mendorong meningkatnya kinerja karyawan,misalnya melalui pendidikan, pelatihan, pemberian kompensasi yang layak, menciptakan lingkungan kerja yang kondusif dan pemberian motivasi. Melalui prosesproses tersebut, karyawan diharapkan akan lebih memaksimalkan tanggung jawab atas pekerjaan mereka karena para karyawan telah terbekali oleh pendidikan dan pelatihan yang tentu berkaitan dengan implementasi kerja mereka.

Sedangkan pemberian kompensasi, lingkungan kerja yang baik serta pemberian motivasi pada dasarnya adalah hak para karyawan dan merupakan kewajiban dari pihak perusahaan untuk mendukung kontribusi para karyawannya dalam rangka mencapai tujuan yang telah ditentukan.

Panggabean

(2004:76)

menyatakan pemberian kompensasi dapat diberikan dalam berbagai bentuk, baik itu finansial maupun nonfinansial. Kompensasi finansial ada yang langsung dan ada yang tidak langsung. Kompensasi finansial langsung terdiri atas gaji/upah dan insentif (komisi dan bonus). Sedangkan kompensasi finansial tidak langsung dapat berupa berbagai macam fasilitas dan tunjangan. Kompensasi nonfinansial terdiri atas pekerjaan dan lingkungan kerja, seperti tugas-tugas yang menarik, tantangan baru yang menarik, pengakuan, rasa pencapaian, kerabat kerja yang menyenangkan, lingkungan kerja yang nyaman dan sebagainya. Pemberian kompensasi sangat penting bagi karyawan, karena besar kecilnya kompensasi merupakan ukuran terhadap prestasi kerja karyawan.

Pemberian kompensasi dapat meningkatkan prestasi kerja dan motivasi karyawan. Oleh karena itu, perhatian organisasi atau perusahaan terhadap pengaturan secara rasional dan adil sangat diperlukan. Bila karyawan memandang pemberian kompensasi tidak memadai, prestasi kerja/, motivasi maupun kepuasan kerja mereka cenderung akan menurun..

Menurut Mangkunegara $(2004,67)$ istilah kinerja berasal dari kata job performance atau actual performance (prestasi kerja atau prestasisesungguhnya yang di capai oleh seseorang). Pengertian kinerja (prestasi) adalah hasil kinerja secara kualitas, kuantitas, yang dicapai oleh seorang pegawai dalam melaksanakan tugasnya sesuai dengan tanggung jawab yang diberikan kepadanya.

PT.Pegadaian (Persero) Kanwil 1 Medan adalah salah satu badan usaha milik pemerintah yang bergerak di bidang pelayanan jasa simpan pinjam. Perusahaan memberikan pelatihan dan pengembangan karyawan setelah dilakukan perekrutan, baik itu pelatihan jasa taksir ataupun pelatihan dalam sistem organisasi. Hal ini sangat menguntungkan perusahaan, karena karyawan yang telah dilatih akan jauh lebih bagus kualitasnya dibandingkan sebelum melakukan pelatihan.

Akan tetapi pelatihan yang diberikan perusahaan kurang mampu meningkatkan kinerja karyawan. Ini bisa dilihat dari karyawan yang telah di latih hanya mengerjakan tugas seadanya. Dan waktu yang tersisa di gunakan karyawan untuk tidur ataupun melakukan aktivitas di luar dari kegiatan perusahaan. 
Vol. 10 No. 1 Maret 2015

Berdasarkan wawancara awal yang penulis lakukan terhadap 5 orang karyawan di PT.Pegadaian (Persero) Kanwil 1 Medan, terdapat 3 orang karyawan yang memiliki keinginan untuk mengundurkan diri. Alasannya karena kompensasi yang ditawarkan oleh perusahaan lain jauh lebih baik dibandingkan di perusahaannya sekarang. Kompensasi yang diberikan perusahaan hanya mampu memenuhi kebutuhan tersier karyawan saja, namun kebutuhan primer dan sekunder masih tidak dapat terpenuhi jika hanya mengandalkan gaji perusahaan sekarang. Mengingat era globalisasi mengakibatkan semakin tingginya gaya hidup masyarakat.

Oleh sebab itu perusahaan harus mampu memotivasi karyawan untuk lebih meningkatkan kinerja mereka, baik itu berupa pemberian kompensasi yang layak ataupun memberikan sarana dan prasarana yang menunjang kegiatan perusahaan. Sebab jika hal ini tidak mendapat perhatian dari perusahaan, bisa saja kinerja karyawan tidak mengalami peningkatan bahkan mengalami penurunan kinerja.

\section{METODE PENELITIAN \\ Lokasi penelitian}

Lokasi penelitian dilaksanakan pada PT.Pegadaian (Persero) Kanwil I Medan Jl.Pegadaian No. 112 Medan.

\section{Populasi dan Sampel}

Pada penelitian ini populasi yang diteliti adalah semua karyawan PT.Pegadaian(Persero) Kanwil I Medan. Karena jumlah populasinya kecil yaitu 56. Sampel dalam penelitian ini bejumlah 56 karyawan.

\section{Variabel Penelitian dan Defenisi} Operasional Variabel Independen
Variabel independen dalam penelitian ini adalah kompensasi, yaitu segala sesuatu yang diterima karyawan sebagai balas jasa untuk kerja mereka. Berikut ini adalah definisi operasional variabel yang digunakan dalam penelitian dengan menggunakan dasar penelitian sebelumnya dan kondisi di tempat penelitian, yaitu:

a. Kompensasi (X1)

Kompensasi menurut Simamora (2004:442) adalah meliputi kembalian finansial dan jasa-jasa terwujud dan tunjangan-tunjangan yang diterima oleh para karyawan sebagai bagian hubungan kepegawaian.

b. Pelatihan (X2)

Menurut (Hani Handoko : 2001:104) pengertian latihan . Latihan (training) dimaksudkan untuk memperbaiki penguasaan berbagal keterampilan dan teknik pelaksanaan kerja tertentu, terinci dan rutin.

\section{Variabel dependen}

Menurut Simamora (2006:339) "kinerja karyawan mengacu kepada kadar pencapaian tugas-tugas yang membentuk sebuah pekerjaan karyawan. Kinerja merefleksikan seberapa baik karyawan memenuhi persyaratan sebuah pekerjaan.

\section{Definisi operasinal}

a. Kompensasi ( X1) adalah imbalan atau balas jasa yang di berikan sesuai tenggang waktu yang telah disepakati yang diberikan oleh perusahaan kepada karyawan sesuai dengan kinerja yang telah ditunjukkan karyawan. Yang terdiri dari kompensasi finansial dan nonfinansial.

Indikator pada kompensasi :
1. Gaji
2. Upah
3. Bonus
4. Insentif 


\section{JURNAL PLANS}

Penelitian Ilmu Manajemen \& Bisnis

Vol. 10 No. 1 Maret 2015

5. Lingkungan kerja

6. Peluang promosi

7. Pengakuan

b. Pelatihan (X2 ) adalah pelatihan adalah suatu proses pendidikan jangka pendek yang mempergunakan prosedur sistematik dan terorganisir dimana pegawai non manajerial mempelajari pengetahuan dan keterampilan teknis dalam tujuan terbatas.

Indikator dari pelatihan adalah :
1. Instruktur
2. Peserta
3. Materi
4. Metode
5. Tujuan
6. Sasaran

c. Kinerja ( Y) adalah hasil atau unjuk kerja yang diperlihatkan atau di hasilkan oleh seseorang atas pekerjaan yang menjadi tanggung jawabnya.

Indikator dari kinerja adalah :

1. kesetiaan

2. prestasi kerja

3. tanggung jawab

4. ketaatan

5. kejujuran

6. kerja sama

7. prakarsa

8. kepemimpinan

\section{Teknik Analisis Data}

\section{Regresi Linier Berganda}

Untuk melihat pengaruh antara dua variabel bebas dan satuvariabel terikat yang ada, dan menggunakan formula:

$$
\mathrm{Y}=\mathrm{b}+\mathrm{b} 1 \mathrm{X} 1+\mathrm{b} 2 \mathrm{X} 2+\mathrm{e}
$$

Diminta :

Y : Variabel terikat (Kinerja

Karyawan)

b : Konstanta

b1 : Koefisien Regresi X1 b2 : Koefisien Regresi X2

$\mathrm{X} 1$ : Variabel Bebas (kompensasi

)

X2 : Variabel Bebas (pelatihan)

\section{Uji Hipotesis \\ Uji F( uji serentak)}

Pengujian hipotesis kedua dilakukan dengan memanfaatkan uji statistik F (uji serentak), dengan rumus (Sudjana, 2005:385):

Keterangan:

$$
\mathrm{F}=\frac{\mathrm{R}^{2} / \mathrm{k}}{\left(1-\mathrm{R}^{2}\right) / \mathrm{n}-\mathrm{k}-1}
$$

$\mathrm{F} \quad=$ rasio

$\mathrm{R} 2=$ hasil perhitungan $\mathrm{R}$ dipangkatkan dua

$\mathrm{k} \quad=$ jumlah variabel bebas

$\mathrm{n} \quad=$ banyaknya sampel

Berdasarkan hipotesis yang telah diajukan di muka, maka untuk pengujian hipotesis (1), diuji sebagai berikut:

Ha : b1 b2 0, artinya secara bersamasama tidak ada pengaruh yang signifikan antara variabel $\mathrm{X} 1, \mathrm{X} 2$ terhadap variabel $Y$.

\section{Uji Statistik t}

Uji statistik t dilakukan untuk menunjukkan seberapa jauh pengaruh satu variabel independen secara individual dalam menerangkan variasi variabel dependen. Dasar pengambilan keputusannya adalah :

1. Jika t-hitung $<$ t-tabel, maka variabel independen secara individual tidak berpengaruh terhadap variabel dependen (hipotesis ditolak).

2. Jika t-hitung $>$ t-tabel, maka variabel independen secara individual berpengaruh terhadap variabel dependen (hipotesis diterima).

Uji $t$ dapat juga dilakukan dengan melihat nilai signifikansi $\mathrm{t}$ 
Vol. 10 No. 1 Maret 2015

masing-masing variabel pada output hasil regresi menggunakan SPSS dengan significance level $0,05(\alpha=$ $5 \%$ ). Jika nilai signifikansi lebih besar dari $\alpha$ maka hipotesis ditolak (koefisien regresi tidak signifikan),
Untuk menguji hipotesis diatas diperlukan analisis regresi linier berganda dengan menggunakan SPSS 20,0 for windows Tingkat kepercayaan yang digunakan dalam menghitung regresi linier berganda

Tabel 1. Koefisien Regresi

Coefficients $^{a}$

\begin{tabular}{|c|c|c|c|c|c|c|}
\hline \multirow{2}{*}{\multicolumn{2}{|c|}{ Model }} & \multicolumn{2}{|c|}{ Unstandardized Coefficients } & \multirow{2}{*}{$\begin{array}{c}\begin{array}{c}\text { Standardized } \\
\text { Coefficients }\end{array} \\
\text { Beta }\end{array}$} & \multirow[t]{2}{*}{$\mathrm{t}$} & \multirow[t]{2}{*}{ Sig. } \\
\hline & & B & Std. Error & & & \\
\hline & (Constant) & 34.939 & 9.553 & & 3.657 & .001 \\
\hline 1 & Kompensasi & .204 & .103 & .258 & 2.980 & .043 \\
\hline & Pelatihan & .397 & .174 & .297 & 2.278 & .027 \\
\hline
\end{tabular}

yang berarti secara individual variabel independen tidak mempunyai pengaruh yang signifikan terhadap variabel dependen. Jika nilai signifikansi lebih kecil dari $\alpha$ maka hipotesis diterima (koefisien regresi signifikan), berarti secara individual variabel independen mempunyai pengaruh yang signifikan terhadap variabel dependen.

\section{HASIL PENELITIAN DAN PEMBAHASAN \\ Hasil Penelitian \\ Uji Regresi Berganda}

Pengujian melalui regresi linier berganda dilakukan untuk menganalisis pengaruh kompensasi dan pelatihan terhadap kinerja karyawanPT.Pegadaian (persro) Kanwil 1 Medan. Sebagaimana hipotesis dalam penelitian ini: $\mathrm{H} 1=$ Ada pengaruh Kompensasi $\left(\mathrm{X}_{1}\right)$ terhadap kinerja karyawan (Y) $\mathrm{H} 2=$ Adanya pengaruh pelatihan $\left(\mathrm{X}_{2}\right)$ terhadap kinerja karyawan( Y) $\mathrm{H} 3=$ Adany pengaruh kompensasi $\left(\mathrm{X}_{1}\right)$ dan pelatihan $\left(\mathrm{X}_{2}\right)$ terhadap kinerja karyawan $(\mathrm{Y})$.

Adapun model regresi berganda adalah sebagai berikut :

$$
\mathbf{Y}=\mathbf{a}+\mathbf{b}_{1} \mathbf{X}_{1}+\mathbf{b}_{2} \mathbf{X}_{2}+\mathbf{e}
$$

adalah $95 \%$ atau dengan tingkat kesalahan 5\% $(0,05)$. Pada analisis regresi linier berganda dilakukan uji f untuk uji secara simultan dan uji $\mathrm{t}$ untuk uji secara parsial. Secara ringkas hasil analisis regresi linier berganda terdapat dalam tabel berikut ini:

Dari pengolahan data, maka dapat dibuat persamaan regresinya . Persamaan regresi :

$Y=34,939+0,204 X_{1}+0,397 X_{2}$ Persamaan regresi dapat dijelaskan sebagai berikut :

a. Konstan sebesar 34,939 menyatakan bahwa jika tidak ada variabel kompensasi (X1) dan variabel pelatihan (X2) maka nilai kinerja (Y) adalah sebesar 34,939.

b. Koefisien regresi variabel kompensasi (X1) sebesar 0,204, artinya jika kompensasi mengalami kenaikan $1 \%$, maka kinerja karyawan (Y) akan mengalami peningkatan sebesar 0,204

c. Koefisien regresi variabel Pelatihan (X2) sebesar 0,397, artinya jika vaiabel pelatihan rmengalami kenaikan $1 \%$ maka kinerja karyawan (Y) akan mengalami peningkatan sebesar 0,397.

Koefisien Determinasi (R Square) 
Vol. 10 No. 1 Maret 2015

Tabel 2. Model Summary ${ }^{b}$

\begin{tabular}{|l|c|r|r|r|}
\hline Model & $\mathrm{R}$ & $\begin{array}{c}\mathrm{R} \\
\text { Square }\end{array}$ & $\begin{array}{c}\text { Adjusted } \\
\mathrm{R} \\
\text { Square }\end{array}$ & $\begin{array}{c}\text { Std. } \\
\text { Error of } \\
\text { the } \\
\text { Estimate }\end{array}$ \\
\hline 1 & $.458^{\mathrm{a}}$ & .209 & .179 & 4.805 \\
\hline
\end{tabular}

Sumber : data diolah, 2014

Untuk mengetahui seberapa besar persentase pengaruh variabel bebas terhadap variabel terikat atau untuk melihat berapa besar variabel bebas dapat menjelaskan variabel terikat maka dilakukan pengujian koefisien determinasi $\left(\mathrm{R}^{2}\right)$.

Dari tabel 2. dapat lihat besarnya angka $\mathrm{R}^{2}$ adalah 0,209 , yang artinya variabel X1dan $\mathrm{X} 2$, menjelaskan pengaruh terhadap variabel $\mathrm{Y}$ sebesar $20,9 \%\left(\mathrm{R}^{2}\right.$ X $100 \% ; 0,209 \times 100 \%=$ $20,9 \%$ ) sedangkan sisanya $79,1 \%$ $\left(100 \%-R^{2}\right)$ dijelaskan oleh variabelvariabel diluar model penelitian ini.

\section{Pengujian Hipotesis}

\section{Pengujian Hipotesis Secara}

Simultan Menggunakan Uji - F

Uji hipotesis secara keseluruhan pada tahap ini adalah untuk melihat apakah model regresi diatas sudah benar atau tidak.

Uji hipotesis menggunakan angka $\mathrm{F}$ yang diperoleh dari tabel Anova di bawah ini :

Tabel 3. Hasil Uji -F

\begin{tabular}{|l|r|r|r|r|r|}
\hline Model & $\begin{array}{c}\text { Sum of } \\
\text { Squares }\end{array}$ & Df & $\begin{array}{c}\text { Mean } \\
\text { Square }\end{array}$ & F & Sig. \\
\hline \multicolumn{1}{|l|}{$\begin{array}{l}\text { Regression } \\
1\end{array}$} & 323.924 & 2 & 161.962 & 7.015 & $.002^{\mathrm{a}}$ \\
$\begin{array}{l}\text { Residual } \\
\text { Total }\end{array}$ & 1223.630 & 53 & 23.087 & & \\
\hline
\end{tabular}

Sumber: data diolah

Berdasarkan Tabel 3. angka $F$ penelitian yang diperoleh dai hasil perhitungan adalah sebesar 7,015. Sedangkan angka $\mathrm{F}_{\text {tabel }}$ dihitung dengan ketentuan yaitu taraf signifikansi $95 \%$ dan alpha 5\% serta derajat kebebasan (dk) dengan ketentuan $n-2=56-2=54$. Dengan ketentuan tersebut diperoleh angka $\mathrm{F}_{\text {tabel }}=2,005$.

Dengan demikian diperoleh nilai $\mathrm{F}_{\text {hitung }}=7,015$, dan $\mathrm{F}_{\text {tabel }}=2,005$. Karena $F_{\text {hitung }}>F_{\text {tabel }}$ yang berarti $\mathrm{H} 1$ diterima, sehingga dapat disimpulkan bahwa kompensasi dan pelatihan berpengaruh positif dan signifikan terhadap kinerja karyawan.

\section{Pengujian Hipotesis Secara Parsial Menggunakan Uji t}

Untuk melihat besarnya pengaruh anatara kompensasi dan pelatihan terhadap kinerja karyawan secara parsial, digunakan $\mathrm{Uji} \mathrm{t}$ dengan menggunakan koefisien regresi.

\section{Pengujian pengaruh kompensasi (X1) terhadap kinerja karyawan}

Secara individual uji statistik yang digunakan adalah uji t. hasil perhitungan SPSS diperoleh angka $t_{\text {hitung }}$ sebesar 2,005.

kriteria uji hipotesis adalah sebagai berikut:

Jika $\mathrm{t}_{\text {hitung }}>\mathrm{t}_{\text {tabel }}$ maka $\mathrm{H}_{1}$ diterima

Jika $\mathrm{t}_{\text {hitung }}<\mathrm{t}_{\text {tabel }}$ maka $\mathrm{H}_{1}$ ditolak

Berdasarkan kriteria tersebut, nilai $t_{\text {hitung }}$ yang di peroleh dari tabel coefficients yaitu 2,980 $>2,005$, maka H1 diterima, artinya hipotesis kompensasi berpengeruh positif terhadap kinerja karyawan.

\section{Pengujian pengaruh pelatihan ( X2)} terhadap kinerja karyawan

Hasil perhitungan SPSS diperoleh angka $t_{\text {hitung }} 2,278$. Untuk memperoleh besarnya $t$ tabel dilakukan perhitungan sebagai berikut: 
Vol. 10 No. 1 Maret 2015

Taraf signifikansi $95 \%$ dan alpha $5 \%$, serta derajat kebebasan (dk) dengan ketentuan $\mathrm{dk}=\mathrm{n}-2$ atau 56-2 = 54. Dari ketentuan tersebut diperoleh $\mathrm{t}$ tabel sebesar 2,005.

Kriteria uji hipotesis adalah sebagai berikut :

Jika $t_{\text {hitung }}>\mathrm{t}_{\text {tabel }}$ maka $\mathrm{H}_{2}$ diterima

Jika $\mathrm{t}_{\text {hitung }}<\mathrm{t}_{\text {tabel }}$ maka $\mathrm{H}_{2}$ ditolak

Berdasarkan kriteria tersebut, nilai $\mathrm{t}$ hitung yang di peroleh dari tabel coefficients yaitu 2,278 $>2,005$, maka H2 diterima, artinya hipotesis pelatihan berpengaruh positif terhadap kinerja karyawan.

\section{Pengujian pengaruh kompensasi dan pelatihan terhadap kinerja karyawan}

Pada tabel 3. nilai $\mathrm{F}$ hitung adalah sebesar 7.015, sedangkan nilai F tabelnya adalah sebesar 3,17 (df $1=$ $3-1=2$ dan df $2=56-2-1=53$ ). Selain itu, nilai signifikansinya adalah sebesar 0,002 lebih kecil daripada taraf signifikansi. $(\alpha) \quad 0,05$. Karena nilai $\mathrm{F}$ hitung $>\mathrm{F}$ tabel $(7,015>3,17)$ dan nilai signifikansi lebih kecil daripada taraf signifikansi $(\alpha) 0,05$ $(0,002<0,05)$, maka hipotesis ketiga diterima, artinya kompensasi dan pelatihan secara simultan berpengaruh positif dan signifikan terhadap kinerja karyawan.

\section{Pembahasan Hasil Penelitian}

Penerapan Pemberian Kompensasi pada PT.Pegadaian (Persero) Kanwil 1 Medan

a. Hasil penelitian variabel kompensasi ( $\mathrm{X}_{1}$ )

Dari hasil regresi berganda diperoleh diperoleh Koefisien regresi variabel kompensasi (X1) sebesar 0,204, artinya jika kompensasi mengalami kenaikan 1\%, maka kinerja karyawan (Y) akan mengalami peningkatan sebesar
0,204. Dari hasil penelitian tersebut dapat dikatakan bahwa kompensasi yang semakin baik akan mempengaruhi kinerja karyawan. Dari hasil jawaban responden menunjukkan bahwa 41, 07 karyawan menyatakan bahwa kompensasi yang mereka terima memuaskan, sedangkan $46,42 \%$ menyatakan cukup puas, dan $12,5 \%$ lagi menyatakan bahwa kompensasi yang diberikan perusahaan tidak memuaskan. Tanggapan responden terhadap variabel kompensasi, terlihat bahwa kompensasi yang dibayarkan cukup layak.

Kompensasi adalah hal dasar yang harus di penuhi oleh perusahaan agar karyawan yang bekerja didalam perusahaan tersebut memiliki motivasi untuk meningkatkan kinerjanya. Kompensasi yang dimaksud bisa berupa kompensasi langsung maupun kompensasi tidak langsung.

b. Hasil penelitian variabel pelatihan Koefisien regresi variabel Pelatihan (X2) sebesar 0,397, artinya jika vaiabel pelatihan rmengalami kenaikan $1 \%$ maka kinerja karyawan (Y) akan mengalami peningkatan sebesar 0,397. Berdasarkan jawaban responden pada variabel pelatihan, $41,07 \%$ menyatakan bahwa pelatihan yang di berikan sangat membantu mereka dalam bekerja dan meningkatkan kinerja mereka, sedangkan $53,57 \%$ menyatakan pelatihan cukup membantu mereka dalam meningkatkan kinerja, dan sisanya $5,35 \%$ menyatakan pelatihan yang telah diberikan oleh perusahaan belum dapat membantu mereka dalam pekerjaan dan peningkatan kinerja mereka. Tanggapan responden terhadap variabel pelatihan pada PT.Pegadaian (Persero) Kanwil 1 Medan adalah baik. Kondisi ini 


\section{JURNAL PLANS}

Penelitian Ilmu Manajemen \& Bisnis

Vol. 10 No. 1 Maret 2015

karena pelatihan yang diberikan cukup membentu mereka dalam mengerjakan tugas-tugas yang diberikan perusahaan.

c. Hasil penelitian kinerja Konstan sebesar 34,939 menyatakan bahwa jika tidak ada variabel kompensasi (X1) dan variabel pelatihan (X2) maka nilai kinerja (Y) adalah sebesar 34,939. Dari jawaban reponden pada variabel kinerja, dapat dilihat 33,92\% karyawan merasa kinerja yang mereka tunjukkan dalam perusahaan sudah sangat baik, mengingat kompensasi. Selanjutnya 59,92\% menyatakan bahwa kinerja yang mereka tunjukkan dalam perusahaan sudah cukup baik, dan sisanya 7,14\% menyatakan belum termotivasi dengan pemberian kompensasi dan pelatihan untuk meingkatkan kinerjanya dalam perusahaan .

\section{PENUTUP}

\section{Kesimpulan}

Penelitian ini dilakukan oleh penulis untuk mengetahui apakah kompensasi dan pelatihan berpengaruh terhadap kinerja karyawan PT.Pegadaian (Persero) Kanwil 1 Medan. Hasil penelitian menjelaskan bahwa kompensasi berpengeruh positif terhadap kinerja karyawan. Artinya kompensasi yang di berikan perusahaan akan mempengaruhi tingkat kinerja yang ditunjukkan oleh perusahaan. Jika kompensasi yang diberikan dianggap layak dana adil maka karyawan akan memberikan kinerja yang baik. Demikaian juga sebaliknya.

Berdasarkan perhitungan SPSS 20,0 for windows untuk melihat berapa besar pengaruh kommpensasi terhadap kinerja karyawan, diperoleh hasil $t_{\text {hitung }}(2.980)<t_{\text {tabel }}(2,005)$, yang berarti $\mathrm{H} 1$ diterima

Dan untuk variabel bebas kedua yaitu pelatihan, hasil penelitian membuktikan bahwa pelatihan berpengaruh positif terhadap kinerja karyawan. Hal ini berarti penilaian karyawan terhadap pelatihan yang diberikan kepada mereka sangat membantu dalam pekerjaan mereka, sehingga dengan adanya pelatihan karyawan akan lebih mudah dalam menyelesaikan tanggung jawabnya dan akan memperlihatkan kinerja yang baik.

Dan untuk hipotesis ketiga yaitu adanya pengaruk kompensasi dan pelatihan terhadap kinerja karyawan PT.Pegadaian (Persero) Kanwil 1 Medan. Karena nilai $F$ hitung $>$ F tabel $(7,015>3,17)$ dan nilai signifikansi lebih kecil daripada taraf signifikansi $(\alpha) 0,05 \quad(0,002<$ $0,05)$, maka hipotesis ketiga diterima, artinya kompensasi dan pelatihan secara simultan berpengaruh positif dan signifikan terhadap kinerja karyawan.

DAFTAR PUSTAKA

Arikunto, Suharsimi, 2003. Prosedur Penelitian Suatu Pendekatan Praktek,

Amrullah, Asriyanti,2012. Pengaruh Kompensasi Finansial dan Nonfinansial terhadap Kinerja Karyawan PT.Bank Rakyat Indonesia (Persero) Tbk. wilayah Makassar

Arep, Ishak dan Hendri Tanjung. 2003. Manajemen Motivasi. Jakarta : PT. Gramedia Widiasarana Indonesia.

Bernadine, H. John. \& Russell, Joyce E.A., 2000, Human Resource Management, Second Edition. Boston: McGraw-Hill International Edition 
JURNAL PLANS

Penelitian Ilmu Manajemen \& Bisnis

Vol. 10 No. 1 Maret 2015

Dessler, 1998. Manajemen Sumber Daya Manusia, Penerbit BPFE, Jogyakarta.

Ghozali,Imam,2012, "Aplikasi Anali sis Multivariate Program SP SS",Semarang: Badan Penerbit UNDIP

Handoko, Hani T, 2003. Manajemen Personalia dan Sumber Daya Manusia. Edisi Kedua. BPFE. Yogyakarta.

Hasan, iqbal. 2002. Pokok-pokok Materi Metodologi Penelitian dan Aplikasinya, Penerbit Ghalia Indonesia, Jakarta.

Hasibuan, Malayu S.P. 2008. Manajemen Sumber Daya Manusia. Edisi Revisi. Jakarta : PT. Bumi Aksara.

Mangkunegara, A. A. Anwar Prabu. 2004. Manajemen Sumber Daya Manusia Perusahaan. Cetakan Kelima. Bandung : PT. Remaja Rosdakarya.

Martoyo, Susilo. 2007. Manajemen Sumber Daya Manusia. Edisi Kelima. Yogyakarta : PT. BPFE.

Muljani, ninuk. 2002. Kompensasi sebagai motivator untuk meningktakan kinerja karyawan.jurnal manajemen $\&$ kewurausahaan vol 4, No. 2: 108-122.Diakses pada tanggal 13 Desember 2014

Mulyadi. 2004. Akuntansi Manajemen : Konsep, Manfaat, dan Rekayasa. Edisi Ketiga. Cetakan Ketiga. Jakarta : Salemba Empat.

Natasari, Dian, 2012. Pengaruh Pemberian Insentif Material dan Nonmaterial Terhadap Kinerja Karyawan Melalui Kepuasan Kerja ( Studi pada
PG Kebun Agung Malang: Jurusan Manajemen FEBUniversitas Brawijaya Malang. Diakses pada tanggal 13 Desember 2014

Nawawi, Hadari. 2005. Manajemen Sumber Daya Manusia : untuk Bisnis yang Kompetitif. Yogyakarta : Gadjah Mada University Press.

Nazir, Moh, 2003. Metode Penelitian. Penerbit Ghalia Indonesia, Jakarta.

Panggabean, Mutiara S. 2004. Manajemen Sumber Daya Manusia. Cetakan Kedua. Bogor Selatan : Ghalia Indonesia.

Pratiwi, Agustin, 2013. Pengaruh Kompensasi Terhadap Kinerja Karyawan Pada PT.Pos Indonesia ( Persero) Kantor Cabang Bangkalan. Skripsi S1. Madura: Fakultas Ekonomi Trunijoyo Madura. Diakses pada tanggal 11 Desember 2014

Priyatno, Dwi, 2010. "Paham analisa statistik data dengan SPSS". Edisi pertama. Yogyakarta : PT. Buku Seru

Rahayu, vebriana. 2013. Pengaruh kepemimpinan, lingkungan kerja fisik, dan kompensasi terhadap kinerja karyawan di PT.PLN Madiun, Jurnal riset manajemen dan Akuntansi. Vol 1. No. 1. Di akses pada tanggal 12 Desember 2014

Rivai, Veithzal, 2004. Manajemen Sumberdaya Manusia Untuk Perusahaan

Dari Teori Ke Praktek, Penerbit PT Raja Grafindo Persada, Jakarta. 
JURNAL PLANS

Penelitian Ilmu Manajemen \& Bisnis

Vol. 10 No. 1 Maret 2015

Salmah, ninin.2012. pengaruh program pelatihan dan pengembangan karyawan terhadap kompetensi karyawan pada PT.Muba Electric $P$ ower Sekayu, jurnal ekonomi dan informasi akuntansi Thn 2012, VOL 2. NO . 3. Diakses pada tanggal 14 Februari 2014

Samsuddin, Sadili. 2006. Manajemen Sumber Daya Manusia. Cetakan Pertama. Bandung : Pustaka Setia.

Sastrohadiwiryo, B. Siswanto. 2005. Manajemen Tenaga Kerja Indonesia Pendekatan Administratif dan Operasional. Cetakan Ketiga. Jakarta : PT. Bumi Aksara.

Siagian, S.P. 2006. Teori Motivasi dan Aplikasinya. Jakarta : Rineka Cipta.

Simamora, Henry. 2006. Manajemen Sumber Daya Manusia. Edisi Ketiga. Yogyakarta: STIE YKPN.
Sugiyono. 2012. Metode Penelitian Kuantitatif Kualitatif dan $R \& D$. Bandung : Alfabeta.

Sunyoto, Agus. 1991. Manajemen Sumber Daya Manusia. Jakarta : STIE IPWI.

Sutanto,eddy.2013.Pengaruh Pelatihan dan motivasi kerja terhadap kinerja karyawan CV Haragon Surabaya, Jurnal AGORA vol.1, No.3, ( 2013) diakses pada tanggal 14 Februari 2014

Syaifullah. 2005. Organisasi. Org Komunitas \& Perpustakaan Online Indonesia. Pengertian Kompensasi dan Jenis / Macam Kompensasi Sdm Upah, Gaji, Insentif, Tunjangan, $d s b .$. Diakses pada tanggal 12 Desember 2013.

Turere, Nitta,2013. Pengaruh pendidikan dan pelatihan terhadap peningkatan kinerja karyawan pada balai pelatihan teknis pertanian Kalasey.Skripsi S1. Fakultas ekonomi, ISSN 2303-1174. Di akses pada tanggal 14 Februari 2014. 